\title{
Gêneros textuais e temas necessários para agir em contextos profissionais e acadêmicos na área de Biotecnologia
}

\author{
Sara Fernandes Lima ${ }^{1}$ \\ IFRJ - Rio de Janeiro \\ arasflima@gmail.com \\ Douglas Rodrigues Moura ${ }^{2}$ \\ IFRJ - Rio de Janeiro \\ douglas.romoura@gmail.com \\ Ana Paula Marques Beato-Canato \\ Universidade Federal do Rio de Janeiro \\ anabeato@uol.com.br
}

\section{Resumo}

Para contribuir com o preenchimento da lacuna existente no contexto brasileiro de pesquisas na área de planejamento de cursos de línguas para fins específicos baseados em gêneros textuais (RAMOS, 2004), apresentamos um mapeamento de gêneros textuais e dos temas necessários para agir em contextos profissionais e acadêmicos da área de Biotecnologia. Tal estudo foi realizado com a aplicação de um questionário aos alunos, professores e técnicos do curso, em uma instituição federal. A análise dos resultados foi embasada nos pressupostos teórico-metodológicos do Interacionismo Sociodiscursivo (ISD) cujos precursores são Bronckart, Schneuwly e Dolz (MACHADO, 2005).

Palavras-chave: necessidades específicas em Biotecnologia; Interacionismo sociodiscursivo; Temas; Gêneros textuais; Questionário.

\footnotetext{
Abstract

Considering the existing gap in the Brazilian context of researches in the area of specific purpose course planning based on text genres (RAMOS, 2004) and trying to contribute to its development, we present the text genres and themes

${ }^{1}$ Aluna do curso de Biotecnologia e bolsista de iniciação científica júnior (CNPq).

${ }^{2}$ Aluno do curso de Biotecnologia e iniciação científica voluntário.

Horizontes de Linguística Aplicada, ano 10, n. 2, jul./dez. 2011
} 
evaluated as necessary to act in professional and academic contexts of the Biotechnology area. To map these necessities, we applied a questionnaire to students and teachers, in a federal institution, and analyzed the results based on the sociodiscoursive interactionism principles, theory which has Bronckart, Schneuwly and Dolz (MACHADO, 2005) as precursors.

Keywords: Specific needs mapping in Biotechnology; Sociodiscoursive Interacionism; Themes and Text genres; Questionnaire.

\section{Introdução}

Para Ramos (2008), a abordagem de línguas para fins específicos foi incorporada ao processo de ensino-aprendizagem de línguas no Brasil, cercada de interpretações equivocadas. Essas interpretações geraram mitos e simplificaram seus objetivos, que foram reduzidos à colaboração para desenvolver estratégias de leitura pelo aprendiz. O trabalho com línguas para fins específicos objetiva colaborar para que o aprendiz compreenda e produza textos em situações acadêmicas e profissionais específicas.

$\mathrm{Na}$ perspectiva interacionista sociodiscursiva, entendemos que os objetivos de um curso de línguas com fins específicos sejam colaborar para o aprendiz desenvolver capacidades de linguagem (DOLZ et al., 1993) necessárias para agir em contextos profissionais e acadêmicos da área em que atua. Ou seja, desenvolver conhecimentos relacionados ao contexto, à organização e aos aspectos linguísticodiscursivos presentes nos gêneros textuais que circulam em determinada área do conhecimento. O curso pode ser organizado com base nos gêneros textuais considerados necessários pelo. Para tanto, é preciso, em primeiro lugar, de acordo com a indicação de Hutchinson e Waters (1987), conhecer as necessidades dos envolvidos.

Necessidade aqui é concebida com base na compreensão do contexto e das percepções dos envolvidos na comunicação, conforme menciona Berwick (1989). Assim, os gêneros textuais e os temas avaliados como constitutivos das esferas em que os profissionais e os estudantes da área de Biotecnologia participam são considerados possíveis e necessários objetos de ensino. 
Com essa visão, o grupo de estudos Linguagem e Educação para Fins Específicos ${ }^{3}$ reúne alunos e pesquisadores do ensino médiotécnico profissionalizante com interesse em desenvolver estudos baseados nos pressupostos teórico-metodológicos do Interacionismo Sociodiscursivo (doravante ISD) que contribuam para um trabalho mais produtivo com línguas para fins específicos.

Um dos projetos desenvolvidos por esse grupo foi intitulado $O$ mapeamento de gêneros textuais necessários para agir em contextos profissionais e acadêmicos diversos ${ }^{4}$. Nessa pesquisa tivemos o objetivo de compreender os conhecimentos que os estudantes dos cursos precisam para agir profissional e academicamente.

Para tanto, um questionário foi desenvolvido por pesquisadores dos cursos técnicos envolvidos (a saber, Cursos técnicos em Alimentos, em Biotecnologia, em Farmácia, em Meio Ambiente e em Química) e aplicado aos professores, aos técnicos e aos alunos matriculados no primeiro semestre de 2010.

Uma das justificativas para realizar este estudo é a lacuna existente no contexto brasileiro de pesquisas na área de planejamento de cursos de línguas para fins específicos baseados em gêneros textuais (RAMOS, 2004) e a defesa desse trabalho por vários pesquisadores (SWALES, 2007; BHATIA, 2007; ARANHA, 2007; BEATOCANATO, 2011, por exemplo). Também foram consideradas razões para realizá-lo as mudanças que a pesquisa favoreceria ao programa da disciplina na instituição em que foi realizada, Instituto Federal de Educação, Ciência e Tecnologia do Rio de Janeiro (IFRJ) - Campus Rio de Janeiro, bem como em outros programas.

${ }^{3}$ Esse grupo, cuja líder é uma das autoras deste texto, foi cadastrado no CPNq, vinculado ao Grupo Linguagem e Educação, da Universidade Estadual de Londrina (UEL). Com a saída da líder do IFRJ, o grupo foi extinto por falta de um pesquisador que tivesse a titulação exigida pelo CNPq para liderá-lo.

$4 \mathrm{O}$ projeto, orientado por uma das autoras deste artigo, procurou mapear as necessidades específicas de cinco cursos da instituição e, para isso, contou com a colaboração de nove estudantes, sendo que cada grupo ficou responsável pelo levantamento das necessidades dos próprios cursos. Dos envolvidos, uma participante, autora deste artigo, era bolsista PIBIC Jr. e os demais eram pesquisadores voluntários ou pesquisadores colaboradores. Aproveitamos para agradecer o apoio financeiro do IFRJ (Rio de Janeiro) e da Capes para a realização da pesquisa.

Horizontes de Linguística Aplicada, ano 10, n. 2, jul./dez. 2011 
Salientamos a relevância do envolvimento de estudantes das áreas específicas que além de participantes da pesquisa, atuaram como pesquisadores responsáveis por ela. Além disso, destacamos a integração propiciada por um projeto desta natureza da área de Ciências Humanas com ênfase em Linguística Aplicada, com alunos, professores e técnicos dos cursos anteriormente mencionados.

Neste artigo, apresentamos os resultados obtidos, ou seja, o mapeamento de necessidades específicas de profissionais e acadêmicos da área de Biotecnologia, tanto relacionadas aos gêneros textuais quanto aos temas. Para isso, iniciamos com um embasamento teórico, no qual apresentamos os princípios do Interacionismo Sociodiscursivo (ISD) que fundamentaram a pesquisa e listamos as características do gênero questionário. A seguir, descrevemos a metodologia utilizada e as análises dos resultados. Finalizamos este texto com algumas considerações finais e os possíveis desdobramentos desta pesquisa.

\section{Princípios do interacionismo sociodiscursivo}

Com foco na compreensão das relações e das transformações sociais e psicológicas a partir das ações do ser humano, o ISD é considerado uma ciência do humano, que utiliza a linguagem como uma forma de analisar processos psicológicos, a saber: a percepção, a cognição, os sentimentos e as emoções (BRONCKANRT, 2003).

A linguagem é definida como um instrumento semiótico, criado pelo homem para se comunicar. Ele a (trans)forma e é (trans)formado por ela de acordo com o meio em que está inserido (BRONCKART, 2003). Portanto, a linguagem pode ser vista sob uma perspectiva dialética e histórica - assim como a evolução humana - já que é construída socialmente e se dirige ao social (BRONCKART, 2008).

A comunicação se efetiva por meio de textos, que, por sua vez, são "produções verbais efetivas, que assumem aspectos muito diversos, principalmente por serem articuladas a situações de comunicação muito diferentes" (BRONCKART, 2003, p.69).

Tais produções são orientadas pelos gêneros textuais, os quais são "tipos relativamente estáveis de enunciados" (BAKHTIN, 2000, p. 
279), determinados pelo objetivo de quem os produz, socialmente aceitos, construídos e em constante transformação e caracterizam a materialização de uma ação de linguagem. Por conseguinte, cabe ao produtor do texto selecionar o gênero textual que julga ser o mais eficiente para desempenhar seus objetivos frente a um interlocutor. E dessa forma, considera o contexto em que esse exemplar textual circulará, o conteúdo a ser transmitido e a resposta esperada (BEATOCANATO, 2009).

Em vista disso, observamos que uma série de fatores pertencentes ao mundo físico e ao mundo sociossubjetivo - influencia a forma de organização de um texto, o que define o contexto de produção. São fatores que abrangem o local, o momento de produção, o interlocutor, o(s) objetivo(s) de tal interação, o lugar social e as posições sociais do emissor e do receptor (BRONCKART, 2003).

Bronckart (2003, p.96) postula que devemos considerar as informações explicitadas em um texto, caracterizadas por "unidades declarativas da língua natural utilizada" e construídas pelo agenteprodutor. Tais informações variam de acordo com a personalidade e são encontradas na memória do agente, de modo a determinarem as ações e as produções textuais desse agente-produtor.

Expostos alguns princípios do ISD, definimos, a seguir, a metodologia de nossa investigação e o gênero textual questionário, instrumento selecionado para obter informações.

\section{Metodologia}

Ao considerar nosso objetivo de pesquisa - mapear os gêneros textuais e temas necessários para agir em contextos profissionais e acadêmicos da área de Biotecnologia -, os participantes da pesquisa e o tempo disponível para a coleta de dados, optamos pela aplicação de um questionário. Avaliamos ser esta a maneira mais indicada para mapear as necessidades profissionais e acadêmicas para agir em diferentes situações de produção da área de Biotecnologia, conscientes das limitações desse instrumento.

Inicialmente, fizemos uma análise quantitativa dos resultados com a soma das respostas dadas a cada pergunta pelos professores e 
técnicos e pelos alunos. Na segunda etapa, os dados dos alunos foram subclassificados de acordo com o período que cursavam. Posteriormente, relacionamos as respostas obtidas e procuramos estabelecer conexões entre pergunta/resposta, pesquisador/pesquisados, período do curso, interesses dos estudantes, visão do curso, observando a natureza dialética do questionário, conforme explicado a seguir.

\subsection{O questionário como instrumento de coleta de dados}

Ninin et al. (2005, s. p.) definem questionário como

uma forma de coleta de dados composta por questões apresentadas por escrito aos participantes, com o propósito de obter dados sobre opiniões, crenças, sentimentos, interesses, expectativas, vivências etc., a respeito de fenômenos não facilmente observáveis.

$\mathrm{Na}$ qualidade de instrumento de pesquisa, ele pode ser visto como um meio efetivo de coleta de dados porque possui versatilidade no momento em que é confeccionado e pode assumir diferentes facetas conforme o público ao qual é destinado, e, ainda assim, permite recolher um nível extremamente alto de informações (DÖRNYEI, 2003).

Além de considerar o número e o perfil dos participantes, Hawi et al (2005, s.p.) lembram que sua elaboração deve ser pautada nos objetivos da pesquisa. Também é preciso observar o tempo disponível, tanto para aplicação quanto para análise dos questionários, e o perfil do pesquisador.

O questionário pode ser constituído de perguntas totalmente abertas, em formas livres, ou totalmente fechadas, nas quais as respostas se limitam às possibilidades dadas pelo pesquisador. Desse modo, impede surpresas, já que as possíveis respostas estão dispostas apenas para preenchimento de lacunas com algum sinal marcador de afirmação ou negação (BABBIE, 2001, apud HAWI et al., 2005).

Em qualquer uma das formas escolhidas, Machado e Brito (2008) alertam que é necessário ponderar sobre a interação e as relações existentes entre pesquisador e participante. Nesse contexto, o 
pesquisador assume o papel de questionador e de autoridade, enquanto o participante é o questionado, que pode ser influenciado pela relação de poder estabelecida. Dessa maneira, a veracidade das informações obtidas pode ser discutível; existe a possibilidade de o pesquisado optar por não se expor ou se envolver com a pesquisa, omitir opiniões ou informações e, inclusive, dar respostas de cunho falso. Isso por diversos fatores, como a não confiabilidade no questionador ou o julgamento que faz da pesquisa.

Desse modo, em uma perspectiva interacionista sociodiscursiva, as respostas apresentadas nos questionários foram analisadas e foram consideradas as possíveis razões para determinadas escolhas. Foram contrastadas as respostas dos professores e dos estudantes, cursando diferentes períodos. A seguir, descrevemos o questionário utilizado.

\subsection{Composição do questionário deste estudo}

Nosso questionário foi organizado em quatro páginas: duas destinadas às informações pessoais e à autorização do uso dos dados e duas diretamente relacionadas ao objetivo desta pesquisa, o mapeamento das necessidades específicas.

A primeira página continha uma área para preenchimento dos dados pessoais do entrevistado (nome, sexo, faixa etária), características profissionais (formação, atuação profissional, área de atuação e tempo de experiência). E, por fim, um espaço para sua assinatura ou rubrica, que optamos por colocar em todas as páginas, seguindo as normas da instituição.

Na segunda página, colocamos a seguinte instrução, seguida de uma lista com quinze temas: Classifique os temas a seguir de acordo com o grau de importância para o contexto profissional e acadêmico da área de Biotecnologia. Marque um X na opção que melhor descreva tal grau. A classificação deveria ser feita em três categorias (essencial, importante ou secundário, níveis de classificação selecionados de acordo com a Escala Likert ${ }^{5}$ ), seguida de um espaço para sugestões de inclusão e/ou exclusão. De forma semelhante, na

\footnotetext{
${ }^{5}$ Com a escala Likert, procura-se registrar o nível de concordância ou discordância com uma declaração dada.

Horizontes de Linguística Aplicada, ano 10, n. 2, jul./dez. 2011
} 
terceira página havia a mesma pergunta matricial colocada na página 2 , seguida de uma listagem de quinze gêneros textuais que deveriam ser igualmente classificados e de uma área para sugestão de inclusão e/ou exclusão.

No final da terceira página, havia uma pergunta aberta para que o entrevistado fornecesse sua opinião a respeito da importância do inglês na instituição ("Em sua opinião, o estudo da língua inglesa traz benefícios aos alunos desta instituição? Em caso afirmativo, quais? Em caso negativo, por que não?'). Por fim, a quarta página, destinada à autorização, continha um breve resumo do projeto e um espaço para a data e assinatura do entrevistado, além de espaços para demais informações pessoais, por exigência da instituição.

$\mathrm{Na}$ primeira versão do questionário, aplicada aos coordenadores de dois outros cursos, havíamos disponibilizado quatro possibilidades de classificação (muito importante, importante, pouco importante e nada importante). Foram listados vinte temas e vinte gêneros textuais. Contudo, os resultados evidenciaram a tendência dos participantes a buscar a neutralidade e, assim, classificarem praticamente todos os itens de importantes.

Diante disso, fizemos alterações e chegamos ao questionário descrito. A opção pela classificação de acordo com a Escala Likert foi motivada pelo fato de conseguir maximizar os diferentes tipos de respostas a serem obtidos e ainda reduzir a extensão do questionário, o que foi considerado positivo ${ }^{6}$.

Outra modificação foi feita na primeira página, na qual havia uma pergunta aberta ("Você considera o estudo do inglês importante dentro da instituição? [ ] Sim ou [ ] Não. Por quê?”). Nossas discussões nos levaram a perceber que dificilmente os entrevistados selecionariam a reposta "não", inclusive por se tratar de uma pesquisa da área.

\footnotetext{
${ }^{6}$ Gostaríamos de fazer um agradecimento ao Grupo Linguagem e Educação, da Universidade Estadual de Londrina, que trouxe contribuições relevantes para nossa investigação, especialmente a Profa. Dra. Gladys Quevedo-Camargo, considerando que suas sugestões de modificações no questionário foram essenciais para a melhor obtenção dos dados e, consequentemente, para a elaboração deste artigo.

138 Horizontes de Linguística Aplicada, ano 10, n. 2, jul./dez. 2011
} 
As listas de gêneros ${ }^{7}$ e de temas que foram incorporadas ao questionário e avaliadas pelos participantes foram formuladas por nós, autores deste artigo. Tivemos por base a estrutura do nosso curso, a consulta aos livros-textos ${ }^{8}$ utilizados no decorrer do curso de Biotecnologia, nosso conhecimento prévio e as pesquisas na internet, além das discussões realizadas em nosso grupo de pesquisa.

A seguir, apresentamos o contexto em que os questionários foram aplicados.

\subsection{Contexto}

A pesquisa foi realizada no Instituto Federal de Educação, Ciência e Tecnologia, Rio de Janeiro, Brasil. Na comunidade, o IFRJ é reconhecido pela formação de técnicos e localiza-se em um prédio de quatro andares na Rua Senador Furtado, no. 121, Maracanã. Os questionários foram aplicados nesta escola que é composta de alunos do ensino técnico (integrado e concomitante/subsequente ao ensino médio), alunos de graduação e de pós-graduação, professores contratados (122), efetivos (125) e substitutos (64), além de servidores que atuam em diversas áreas, de Psicologia à limpeza. A instituição comporta uma cantina, um auditório, uma quadra poliesportiva (em reformas), uma sala de musculação, uma biblioteca, uma sala de artes, duas salas de informática e 24 laboratórios, além de 25 salas administrativas.

Ressaltamos que a instituição objetiva a formação de profissionais responsáveis por suas ações e, assim, os alunos têm total liberdade para tomar decisões, inclusive quanto à entrada/saída e presença em sala de aula. Nesse ambiente, o esperado é que os estudantes amadureçam já que são responsáveis pelas próprias decisões, que comprometem o desempenho e o futuro de cada aluno dentro e fora da instituição.

\footnotetext{
${ }^{7}$ É necessário dizer que não foi feita uma distinção entre gêneros e suporte. Como o objetivo era possibilitar que todos os participantes compreendessem todos os termos, optamos pelo emprego dos termos mais utilizados em nosso contexto.

${ }^{8}$ Tortoga, G. J., et al. Microbiologia. 6. ed. São Paulo: Artmed, 2003; Lehninger, A. L. et al. Princípios de Bioquímica. 3. ed. São Paulo: Sarvier, 2002.; Stryrer, L. Bioquímica. 3. ed. Rio de Janeiro: Guanabara Koogan, 1996; Bier, O. Microbiologia e Imunologia. 30. ed. São Paulo: Melhoramentos, 1990.
}

Horizontes de Linguística Aplicada, ano 10, n. 2, jul./dez. 2011 
Em relação aos alunos entrevistados, fazem parte do Curso Técnico Integrado ao Ensino Médio de Biotecnologia, do terceiro ao oitavo períodos. A carga horária total do curso é 486 horas semestrais, divididas de segunda-feira a sábado, do terceiro ao sétimo períodos. No oitavo período as 405 horas semestrais, ocorrem de segunda à sexta-feira, com estágio curricular supervisionado. Em relação à disciplina de Inglês para fins específicos, seu objetivo é contribuir para o desenvolvimento de capacidades de linguagem voltadas para a atuação acadêmica e profissional de cada curso. A carga horária total dessa disciplina é menor do que em escolas regulares, 108 horas, divididas em três semestres. Em contrapartida, o número de alunos por turma é reduzido (no máximo vinte), o que contribui para um trabalho direcionado e focado em necessidades específicas.

Nos períodos iniciais, primeiro e segundo semestres, as disciplinas que compõem as grades curriculares são comuns a todos os cursos, diferenciando-se somente a ordem em que são lecionadas. Porém, a partir do terceiro período, há diferenças que procuram atender às necessidades de cada curso, o que se amplia gradativamente até o oitavo período, quando as disciplinas são exclusivamente técnicas. Além disso, os alunos de sétimo/oitavo períodos têm mais conhecimento das suas necessidades profissionais, já que se aproximam mais do mercado de trabalho enquanto estagiam.

Outra característica a ser destacada é a possibilidade de o aluno ser bolsista da instituição, de atuar em laboratórios, na biblioteca ou na sala de artes, o que contribui para a formação desses aprendizes.

Essa organização do curso de Biotecnologia justifica nossa opção por contar com a participação apenas de estudantes que cursavam do terceiro ao oitavo períodos, totalizando 105 alunos entrevistados, por avaliarmos que os alunos dos primeiros anos ainda não estariam familiarizados com seus cursos técnicos. Os questionários foram respondidos com nossa presença, para sanar possíveis dúvidas, durante o turno matutino, entre os intervalos, ou anterior/posterior a uma aula em que grande parte dos alunos houvesse comparecido.

Com relação aos professores, participaram da pesquisa vinte e quatro docentes contratados ou efetivos da área de Ciências Biológicas, grande parte deles coordenadores de algum setor da instituição. Pela razão apontada previamente, os questionários foram 
respondidos com nossa presença, no momento em que os professores estivessem disponíveis, fosse durante os intervalos ou em meio a uma aula prática (dentro do laboratório, onde se tem mais de um professor presente). Contamos com a colaboração de todos os professores da área, inclusive dos coordenadores da Área de Biotecnologia, de Ensino, de Pesquisa, de Ciências Biológicas (Graduação), de Ensino de Ciências e ainda do Diretor de Ensino, também integrante da equipe. Ainda, os pesquisadores presentes na instituição são professores efetivos ou contratados que lecionam na área de Biotecnologia, e estes também foram envolvidos. Ressaltamos que o corpo docente da instituição é composto por professores com dedicação exclusiva e professores que atuam em outras instituições, por exemplo, institutos de pesquisa. Boa parte deles tem mestrado ou doutorado e é pesquisador do IFRJ.

Apresentada a metodologia, passamos à análise dos resultados obtidos.

\section{Análise dos dados}

Iniciamos a análise com a contabilização manual das respostas, separadas por turmas e organizadas em tabelas para facilitar a visualização e interpretação dos dados. Com os resultados obtidos, confeccionamos gráficos compostos das percentagens dos itens classificados de acordo com os graus de importância. Optamos por criar gráficos separados para professores e alunos para possibilitar comparações. Como apontam Hutchinson e Waters (1987), é possível haver divergências entre os participantes. A análise dos dados separadamente permite o contraste de resultados e a percepção de semelhanças e de diferenças e a escolha mais consciente dos gêneros e dos temas a serem trabalhados.

A figura 1 sintetiza as respostas dos professores e técnicos referentes aos temas.

Ao observar a figura 1, detectamos que, dentre os temas classificados em ordem de importância, os mais considerados essenciais foram "Biossegurança", seguido de "DNA" e "Influência da Biotecnologia sobre o meio ambiente e seus usos para preservá-lo", 
ambos com a mesma percentagem, o que não surpreende, tendo em vista que os dois últimos temas são os mais comentados e lembrados quando se trata de biotecnologia. Desse modo, a biossegurança é considerada imprescindível em uma área que lida com agentes que podem ser nocivos à biodiversidade.

\begin{tabular}{|c|c|c|c|c|}
\hline Bioética & 4.16 & 41.67 & & 54.17 \\
\hline Biossegurança & 8.33 & & & 91.67 \\
\hline Biossíntese & 8.34 & 45.83 & & 45.83 \\
\hline Biotransformação & 16.67 & 50 & & 33.33 \\
\hline Distúrbios Cromossomiais & 12.5 & & 66.67 & 20.83 \\
\hline DNA & 8.34 & 33.33 & & 58.33 \\
\hline Histologia e Anatomia Humana & 25 & & 62.5 & 12.5 \\
\hline História da Ciência & 20.84 & & 58.33 & 20.83 \\
\hline Imunodeficiências & 20.83 & & 66.67 & 12.5 \\
\hline Influência da Biotecnologia "1 & 4.17 & 37.5 & & 58.33 \\
\hline Mecanismos de Patogenicidade ${ }^{\mathbf{n} 2}$ & 4.17 & 58.33 & & 37.5 \\
\hline Preparo de Antibióticos ${ }^{n 3}$ & 8.34 & 45.83 & & 45.83 \\
\hline Projeto Genoma & 12.5 & 33.33 & & 54.17 \\
\hline Sinalização Celular & 16.66 & 41.67 & & 41.67 \\
\hline Técnicas de Microscopia & 20.83 & 41.67 & & 37.5 \\
\hline $\begin{array}{r}\text { Figl } \\
p\end{array}$ & 1. & $\begin{array}{l}\text { ndário Importante } \\
\text { ão dos temas } \\
\text { e técnicos }\end{array}$ & Essencial & \\
\hline
\end{tabular}

Os temas considerados importantes foram: "Distúrbios cromossomiais", "Imunodeficiências" e, em seguida, "Histologia e Anatomia Humana". Concomitantemente, este último também foi mais considerado secundário por vários professores, seguido de "História da Ciência" e "Técnicas de Microscopia". A diferença na classificação desse tema pode resultar de sua relevância para a disciplina que cada professor leciona, ou seja, as avaliações podem ter sido influenciadas pela área de atuação de cada professor que, às vezes, atua em mais de um curso e tem uma visão diferenciada das necessidades específicas. A

\footnotetext{
${ }^{9}$ n1: Influência da Biotecnologia sobre o meio-ambiente e seus usos para preservá-lo

n2: Mecanismos de Patogenicidade dos Microrganismos

n3: Preparo de Antibióticos/Vacinas/Antivirais e suas reações no organismo em nível celular 
diferença é compreensível e evidencia o quanto, ao planejar o conteúdo programático da disciplina de Inglês para Fins Específicos, o responsável precisará avaliar a relevância do tema para o grupo de estudantes.

Antes de finalizar a análise dos resultados dos professores e técnicos, apresentamos a figura 2, com as respostas dos alunos referentes aos temas, para serem contrastadas posteriormente.

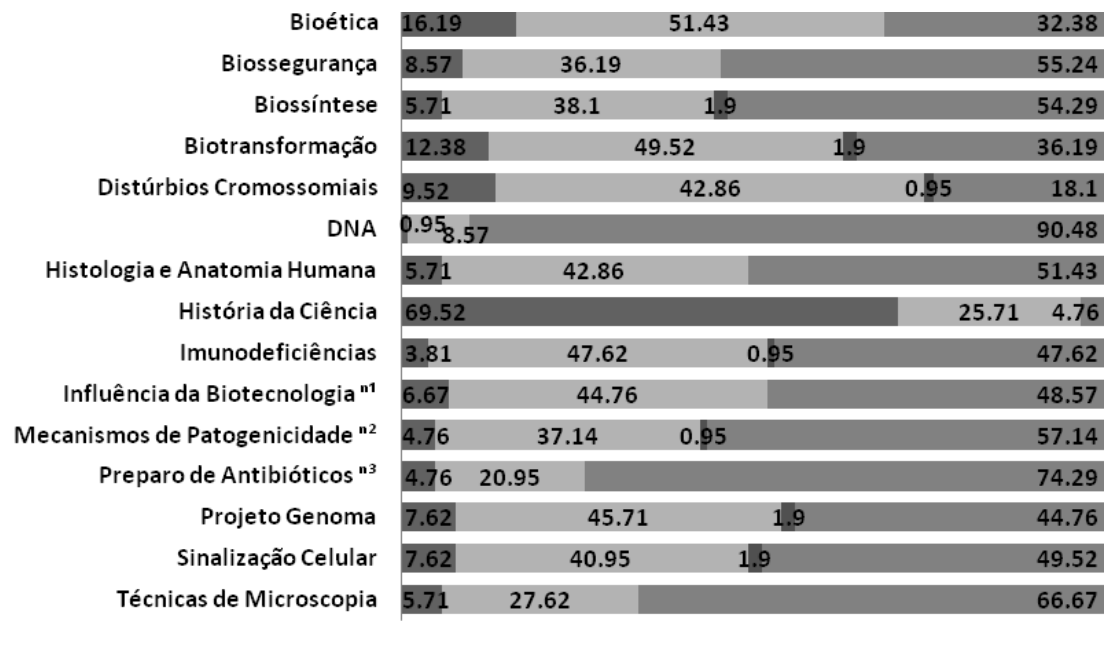

Figura 2. Classificação dos temas pelos alunos

É notável que, entre os alunos, "DNA", "Preparo de Antibióticos/Vacinas/Antivirais e suas reações no organismo a nível celular" e "Técnicas de Microscopia" foram considerados os temas mais essenciais, respectivamente. Porém, "Bioética", "Biotransformação" e "Imunodeficiências" foram os temas classificados de importantes, seguidos de "História da Ciência", "Bioética" e "Biotransformação" os considerados secundários. Ao contrastar estes resultados aos dos professores, acreditamos que a falta de uma visão mais abrangente da área por alguns participantes, devido ao período que frequentavam, influenciou nas respostas, distanciandoos dos resultados dos professores. Nossa hipótese se baseia nas semelhanças que encontramos entre as respostas dos alunos que estavam no final do curso e as dos professores. 
A organização do curso também pode ter contribuído para as diferenças. Para exemplificar, ao compararmos o questionário dos alunos aos dos professores, "Técnicas de Microscopia" e "Bioética" são dois dos temas que mais chamam a atenção, já que docentes e discentes têm opiniões divergentes a respeito. Enquanto "Técnicas de Microscopia" é um tema estudado em vários períodos, mais especificamente $3^{\circ}, 4^{\circ}, 7^{\circ}$ e $8^{\circ}$, "Bioética" é apresentada somente no $6^{\circ}$. Essa estrutura do curso certamente influencia a visão dos estudantes sobre a relevância de cada tema.

Com base em Machado e Brito (2008), outro fator que pode ter influenciado as respostas é o papel social dos envolvidos e a possibilidade de os estudantes não terem se sentido confortáveis para solicitar esclarecimentos sobre algum tema pelo fato de os pesquisadores serem seus colegas de curso.

A partir das análises das figuras 1 e 2, com vista a colaborar com professores de Inglês para Fins Específicos para Biotecnologia, selecionamos alguns temas que poderiam fazer parte do conteúdo programático da disciplina. Para isso, baseamo-nos tanto na opinião dos professores e técnicos - os principais responsáveis pela formação acadêmica e profissional dos estudantes - e dos alunos - que nos revelam seus interesses e a visão que têm sobre a o conteúdo do curso. Também consideramos a grade curricular do nosso curso, de acordo com cada período, além de conhecermos os objetivos da disciplina de Inglês para fins específicos e a carga horária disponível. Para o $5^{\circ}$ período, julgamos relevante a presença dos seguintes temas: "Biossegurança", "Distúrbios Cromossomiais e/ou Hereditários", "Mecanismos de Patogenicidade dos Microrganismos" e "História da Ciência". Já para o $6^{\circ}$ período, sugerimos temas sobre "DNA", "Projeto Genoma", "Imunodeficiências" e "Sinalização Celular". E, por fim, para o $7^{\circ}$ período, destacamos os temas "Influência da Biotecnologia sobre o meio ambiente e seus usos para preservá-lo", "Biotransformação", "Bioética" e "Preparo de Antibióticos/Vacinas/Antivirais e suas reações no organismo em nível celular".

Finalizada a análise dos temas, passamos para os gêneros textuais: iniciamos com a figura 3 , em que se encontram as percentagens com as classificações dos professores. 
Sara F. Lima, Douglas R. Moura \& Ana Paula M. Beato-Canato

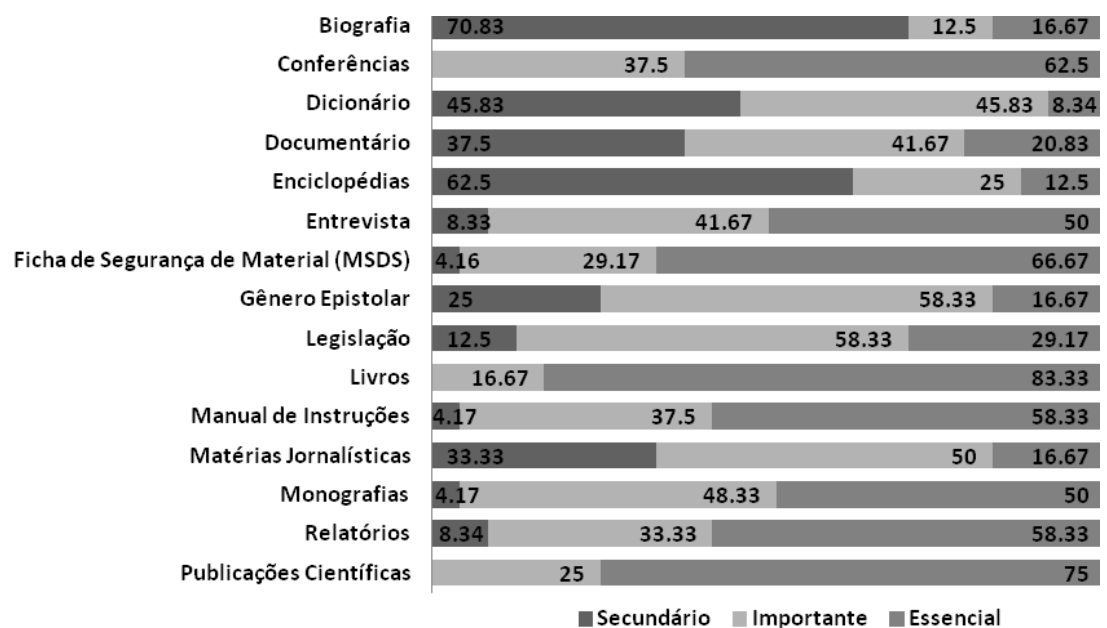

Figura 3. Classificação da relevância dos gêneros textuais pelos professores e técnicos

Distintamente do que ocorreu com os temas, quanto aos gêneros não observamos divergências entre os professores e técnicos participantes da pesquisa, isso sugere que a relevância dos gêneros textuais listados não depende das áreas específicas dentro da Biotecnologia. Destacamos o gênero "Relatórios" considerado um dos mais essenciais, conforme observamos nesta figura. Junto com ele, outros gêneros, a saber: "Ficha de Segurança de Material (MSDS)" e "Manual de Instruções" revelam a característica técnica prezada na instituição, uma vez que mais da metade dos entrevistados os classificaram essenciais. Apesar de não ter sido classificado essencial pela maioria dos participantes, ressaltamos o gênero "Legislação", cuja linguagem utilizada neste gênero é igual, ou similar, à empregada nos gêneros anteriormente descritos neste parágrafo.

Dentre os gêneros classificados essenciais encontram-se: "Livros", "Publicações Científicas", "Conferências" e "Monografias". Avaliamos que este resultado seja decorrente do perfil do curso e dos participantes, pois muitos professores e alunos do curso técnico de Biotecnologia dedicam-se à área acadêmico-científica, esfera em que tais gêneros circulam. 
Embora consideremos importante conhecer o contexto sóciohistórico da área, foram poucos os entrevistados que qualificaram essencial o gênero "Biografia". Talvez por não ser um gênero que circule diretamente em espaços profissionais ou acadêmicos da área. Outros gêneros textuais classificados secundários foram "Verbetes de enciclopédias", "Verbetes de dicionário" e "Gêneros Epistolares", possivelmente pela mesma razão apontada. "Matérias Jornalísticas" também foram consideradas pela metade dos entrevistados importantes, apesar de poderem ser vistas como um meio de divulgação e de popularização da ciência, por exemplo.

Para completar, o gênero "Entrevista" (de emprego) foi bastante classificado tanto como essencial quanto como importante, revelando o interesse institucional em inserir os alunos no mercado de trabalho.

Feitas as observações acima, seguimos para a figura 4, na qual se encontram as percentagens referentes às classificações dos gêneros textuais pelos alunos para poder contrastar às respostas obtidas.

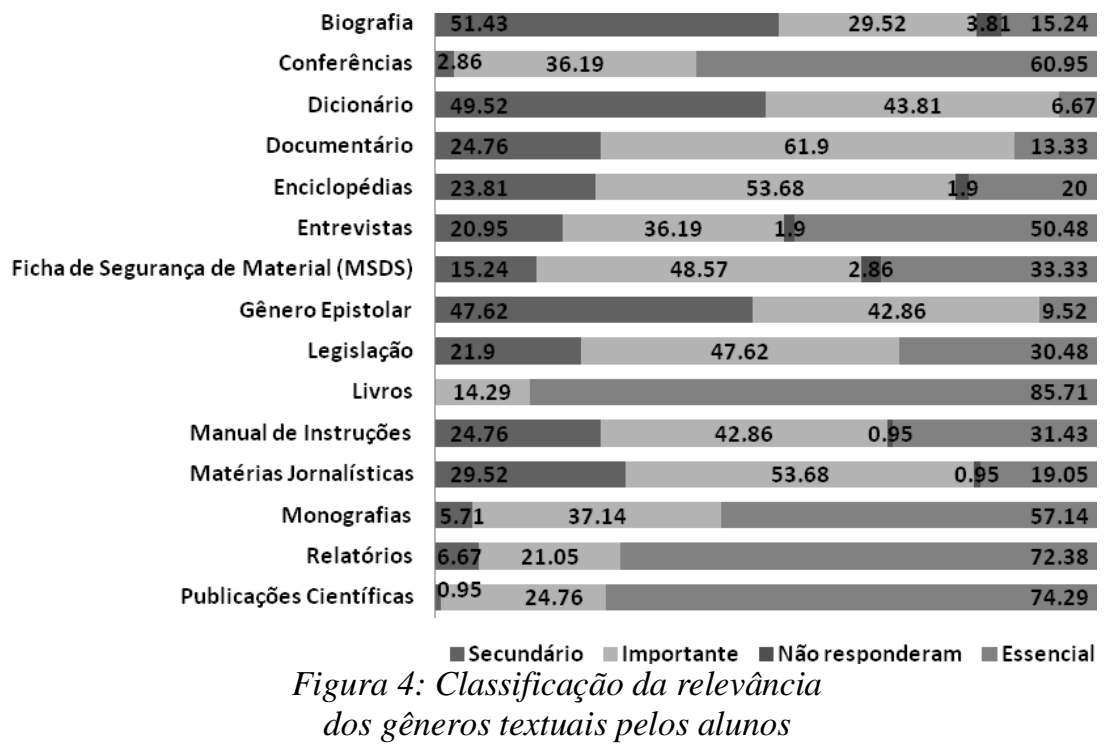

A observação dos resultados nos permite apontar diferenças na percepção do foco da instituição por parte dos professores e dos 146

Horizontes de Linguística Aplicada, ano 10, n. 2, jul./dez. 2011 
alunos, já que os gêneros textuais que circulam em esferas técnicas foram marcados como importantes ("MSDS" e "Manual de Instruções") pela maioria dos alunos em vez de serem considerados essenciais, conforme era esperado. Contudo, o gênero "Relatórios", também presente nesta categoria, foi classificado essencial pela maioria, provavelmente pelo fato de os alunos terem de produzir textos dessa natureza ao longo do curso.

Por outro lado, os gêneros que circulam na esfera acadêmicocientífica ("Livros", "Publicações Científicas", "Conferências" e "Monografias") foram todos classificados como essenciais, o que não surpreende, visto que, no curso de Biotecnologia, são grandes as prospecções para a atuação acadêmico-científica e, talvez por essa razão, é possível afirmar que o curso, apesar de técnico, seja mais voltado para esse contexto do que para o contexto industrial.

Contudo, o Gênero "Entrevista de emprego" também foi indicado pelos estudantes como essencial, o que pode revelar o interesse de serem inseridos no mercado de trabalho.

Similarmente aos professores e técnicos, os gêneros textuais "Biografia", "Verbete de enciclopédias", "Matérias Jornalísticas", "Verbete de dicionário" e "Gêneros Epistolares" não obtiveram classificação significativa. E isso reforça a ideia de que o contexto histórico não é compreendido como essencial para a formação do profissional de Biotecnologia.

Em uma análise comparativa, tanto de gêneros quanto de temas, foi possível notar que a avaliação dos alunos de períodos finais é similar à dos professores e técnicos, com certeza em virtude de uma visão mais ampla do curso, diferentemente dos alunos de períodos iniciais. Um exemplo seria o fato de a maioria desses alunos ter considerado "Biossegurança" um tema secundário ou importante, ao passo que, entre os professores, não houve nenhuma classificação como secundária e $92 \%$ deles consideraram Biossegurnaça um tema essencial. Esses resultados confirmam a relevância do contexto, conforme defendido pelo ISD e descrito anteriormente.

$\mathrm{O}$ cruzamento de dados permite-nos averiguar que a convivência com os professores e o aprofundamento de conhecimentos na área são decisivos, nas escolhas dos alunos, assim como a percepção do grupo em relação ao curso e ao contexto de atuação 
profissional. $\mathrm{O}$ fato de as opiniões dos alunos do $7^{\circ}$ e do $8^{\circ}$ períodos assemelharem-se mais às dos docentes pode indicar a maturidade, a formação e a (trans)formação ocasionada pela vivência com os professores de maneira mais intensiva a partir do $6^{\circ}$ período, quando as disciplinas específicas integram toda a grade.

Igualmente aos alunos de períodos avançados, os resultados obtidos com estudantes bolsistas, que atuam em laboratórios, também se assemelharam mais aos dos professores. Isso nos leva a concluir que o contato mais direto com a área de atuação e com os profissionais da área permite uma percepção mais ampla das necessidades específicas.

No final de nosso questionário, em um espaço para que fossem feitas sugestões de inclusão e/ou exclusão de temas e gêneros, a maioria dos professores e dos técnicos participantes inseriu "Cultura de células", tanto vegetais quanto animais.

Com base nas análises das figuras 3 e 4, indicamos alguns gêneros textuais para a disciplina de Inglês para fins específicos no curso de Biotecnologia, de modo a considerar tanto sua relevância quanto a complexidade de compreensão em língua estrangeira. Para o $5^{\circ}$ período, sugerimos "Biografia", "Ficha de Segurança de Material (MSDS)", e "Manual de Instruções". Já para o 60, destacamos os seguintes gêneros: "Conferências", "Livros (didáticos e teóricos)" e "Monografias (monografias, dissertações e teses". Por fim, para o $7^{\circ}$ período, sugerimos "Documentário", "Matérias Jornalísticas" e "Publicações Científicas (artigos científicos)".

Antes de finalizar, gostaríamos de mencionar que, embora "Matérias jornalísticas" não tenham sido consideradas essenciais, vários professores sugeriram o uso de materiais dessa natureza. Dessa forma, com base em sugestões feitas por alguns professores, nos questionários, também indicamos para todos os períodos, especialmente $6^{\circ}$. e $7^{\circ}$, a consulta a revistas e sites de publicações científicas. Por exemplo: CDC (Centers For Disease Control and Prevention), NCBI (National Center for Biotechnology Information), ANBio (Associação Nacional de Biossegurança), Nature, Science, WHO (World Health Organization), Oxford Journals, Cambridge Journals Online, Yale (Yale - Office Of Public Affairs \& Communications). 


\section{Considerações finais}

Conforme explicitamos no início do texto, o objetivo de nossa investigação era mapear os gêneros textuais e os temas necessários para agir em contextos acadêmicos e profissionais de Biotecnologia. Para isso, contamos com a participação de professores, alunos e técnicos da área, como sugerem Hutchinson e Waters (1987). A opção pelo levantamento de gêneros textuais necessários e pela sugestão de um currículo organizado em gêneros em temas encontra base nos pressupostos do ISD, que, em uma perspectiva bakhtiana, defende que nossas ações são mediadas por gêneros textuais.

Os resultados nos possibilitaram avançar e encontrar subsídios para fazer sugestões para o planejamento da disciplina de Inglês dividida em três períodos, de modo a abranger gêneros textuais e temas diferentes, considerados essenciais, importantes e até secundários por alunos e professores dos períodos estudados.

Destacamos a oportunidade de aproximar duas áreas distintas, as Ciências Humanas e as Ciências Biológicas, por meio desse estudo, e de compreender de forma mais ampla o curso de Biotecnologia, os objetivos da disciplina de Inglês para Fins Específicos, e, inclusive, os objetivos de outras disciplinas da área de Humanas. Este estudo nos ajudou a verificar como as atividades sociais apoiam-se nas atividades linguageiras e que as formas semióticas são necessárias para a regulação dessas atividades (MACHADO, 2005).

Um desdobramento possível, e previsto em nosso projeto, seria a análise das características dos gêneros textuais incluídos no programa. A investigação possibilitaria selecionar de maneira informada as características contextuais, discursivas e linguísticodiscursivas de cada gênero. Essas características poderiam ser empregadas no material didático a ser elaborado, o que também poderia ser inserido no programa da disciplina, de modo a colaborar com professores.

Por fim, defendemos que os programas de Inglês para Fins Específicos não podem se limitar a trabalhar com estratégias de leitura e com elementos linguísticos presentes nos textos, mas precisam evoluir na direção apontada por Bronckart (2003, p.85), de que é preciso conter uma diversificação dos gêneros textuais propostos, além 
de "novas noções para conceitualizar alguns parâmetros e mecanismos que entram em jogo nas atividades de produção". Acreditamos ter contribuído, nesse sentido, ao notarmos que, apesar das divergências teóricas entre os professores da equipe, mudanças foram efetuadas na ementa da disciplina de Inglês para Fins Específicos na instituição onde esta pesquisa foi realizada. Desse modo, foram acrescentados, na disciplina, os temas que sugerimos e especialmente os gêneros textuais, que não eram abrangidos antes da realização deste estudo.

\section{Referências}

ARANHA, Solange. The development of a genre-based writing course for students in three fields. In: $4^{\circ}$. SIMPÓSIO INTERNACIONAL DE ESTUDOS DE GÊNEROS TEXTUAIS, 2007, Tubarão (SC). Anais... Tubarão, 2007. CD ROM.

BAKHTIN, M. Os gêneros do discurso. In: . Estética da criação verbal. Trad. Maria E. G. G. Pereira. São Paulo: Martins Fontes, 2000. p. 279-326.

BATHIA, Vijay K. Interdiscursivity in critical genre analysis. In: $4^{\circ}$. SIMPÓSIO INTERNACIONAL DE ESTUDOS DE GENEROS TEXTUAIS, 2007, Tubarão (SC). Anais... Tubarão, 2007. CD ROM.

BEATO-CANATO, Ana Paula M. O desenvolvimento da escrita em língua inglesa com o uso de sequências didáticas contextualizadas em um projeto de troca de correspondências. 2009. Tese (Doutorado em Estudos da Linguagem) - UEL, Londrina, 2009.

- O trabalho com línguas para fins específicos em uma perspectiva interacionista sociodiscursiva. Revista Brasileira de Linguística Aplicada, Belo Horizonte, v.11, n.4, p.853-870, 2011.

BERWICK, Richard. Needs assessment in language programming: from theory to practice. In: JOHNSON, Robert K. (ed.) The second language curriculum. Cambridge: Cambridge University Press, 1989. p. $48-62$. 
BRONCKART, Jean Paul. Atividade de linguagem, textos e discursos: por um interacionismo sócio-discursivo. Trad. Anna Rachel Machado, Péricles Cunha. São Paulo: EDUC, 2003.

- O Quadro do Interacionismo Sociodiscursivo (ISD). In: . O agir nos discursos: das concepções teóricas às concepções dos trabalhadores. Trad. Anna Rachel Machado, Maria de Lourdes Meirelles Matencio. Campinas, SP: Mercado de Letras, 2008.

DÖRNYEI, Zöltan; TAGUCHI, Tatsuya. Questionnaires in second language research: construction, administration and processing. London: LEA, 2003. p. 1-21.

HAWI, Mona M; MELLO, Dilma M. de; DAMIANOVIC, Maria C.; NININ, Maria O. G. Questionários e programas de formação em serviço: analisando e cruzando dados. Claritas, São Paulo, v. 11, p. 113-141, 2005. Disponível em: <http://www.linguagemeformacao.com.br/linguagemeformacao/produ caoacademica_3questionarioseprogramasdeformacaoemservico.htm>. Acesso em: 19 jun 2011.

HUTCHINSON, Tom; WATERS, Alan. English for specific purposes: a learning-centred approach. Cambridge: Cambridge University Press, 1987. p. 53-63.

MACHADO, Anna Raquel. A perspectiva interacionista sociodiscursiva de Bronckart. In: MEURER, José Luiz; BONINI, Adair; MOTTA-ROTH, Désirée. Gêneros: teorias, métodos, debates. São Paulo: Parábola Editorial, 2005.

MACHADO, Anna Raquel; BRITO, Célia M. C. O agir de enunciadores em questionários de pesquisa. In: COUTINHO, Maria A; MIRANDA, Florencia. (Org.). Linguagem e desenvolvimento: perspectivas epistêmicas e praxiológicas. Estudos Linguísticos/ Linguistic Studies, n. especial (outubro 2008), Universidade Nova de Lisboa. 
NININ, Maria O. G.; HAWI, Mona M.; MELLO, Dilma M.; DAMIANOVIC, Maria C. Questionários: instrumentos de reflexão em pesquisas em Lingüística Aplicada. Contexturas, São Paulo, v. 8, p. 91-114, 2005.

Disponível

em: <http://www.linguagemeformacao.com.br/linguagemeformacao/iframe _producaoacademica_7questionariosinstrumentosdereflexao.htm>. Acesso em: 19 abr 2011.

RAMOS, Rosinda de C. G. Gêneros textuais: uma proposta de aplicação em cursos de inglês para fins específicos. The ESPecialist, v. 25, n. 2, p. 107-129, 2004.

. ESP in Brazil: history, new trends and challenges. In: KRZANOWSKI, Mark. (Org.) English for academic and specific purposes in developing, emerging and least developed countries. Canterbury: IATEFL, 2008. V. 1, p.68-83.

SWALES, John M. Worlds of genre: metaphors of genre. In: $4^{\circ}$. SIMPÓSIO INTERNACIONAL DE ESTUDOS DE GENEROS TEXTUAIS, 2007, Tubarão (SC). Anais... Tubarão, 2007. CD ROM.

\section{Recebido em: 21/09/2011 Aceito em: $\quad$ 25/05/2012}

Title: Necessary text genres and themes to act in professional and academic contexts in Biotechonology 